\title{
Assessment of the Effects of Thermal Power Plant Site and Design Alternatives on the Cost of Electric Power
}

by

Karen A. McGinnis

Jeffrey C. King

September 1977

Prepared for the Energy Research and Development Administration under Contraci EY-76-C-06-1830 


\section{NOTICE}

This report was prepared as an account of work sponsored by the United States Government. Neither the United States nor the Energy Research and Development Administration, nor any of their employees, nor any of their contractors, subcontractors, or their employees, makes any warranty, express or implied, or assumes any legal liability or responsibility for the accuracy, completeness or usefuiness of any information, apparatus, product or process disclosed, or represents that its use would not infringe privately owned rights.

The views, opinions and conclusions contained in this report are those of the contractor and do not necessarily represent those of the United States Government or the United States Energy Research and Development Administration.

PACIFIC NORTHWEST LABORATORY

operated by

BATTELLE

for the

ENERGY RESEARCH AND DEVELOPMENT ADMINISTRATION

Under Contract EY-76-C-06-1830

\begin{tabular}{|c|c|}
\hline \multicolumn{2}{|c|}{$\begin{array}{l}\text { Printed in the United States of Ame } \\
\text { Available from } \\
\text { National Technical Information Ser } \\
\text { U.S. Department of Commerce } \\
5285 \text { Port Royal Road } \\
\text { 5pringfield, Virginia 22151 }\end{array}$} \\
\hline ce: Printed Cop & -*: Microfich \\
\hline - Pages & $\begin{array}{c}\text { NTIS } \\
\text { Selling Price }\end{array}$ \\
\hline $001-025$ & $\$ 4.50$ \\
\hline $026-050$ & $\$ 5,00$ \\
\hline $051-075$ & $\$ 5.50$ \\
\hline $076-100$ & $\$ 6.00$ \\
\hline $101-125$ & 56.50 \\
\hline $126-150$ & 57.00 \\
\hline $151-175$ & $\$ 7.75$ \\
\hline $176-200$ & $\$ 8.50$ \\
\hline $201-225$ & $\$ 8.75$ \\
\hline $226-250$ & $\$ 9.00$ \\
\hline $251-275$ & $\$ 10.00$ \\
\hline $276-300$ & $\$ 10.25$ \\
\hline
\end{tabular}


by Karen A. McGinnis Jeffrey C. King

September 1977

BATTELLE

Pacific Northwest Laboratories

Richland, WA 99352 


\section{CONTENTS}

LIST OF FIGURES

LIST OF TABLES

FOREWORD

INTRODUCTION

REVIEN OF COSTING AND ECONOMIC PROCEDURES

PRIVATE COSTS

EXTERNAL COSTS

APPLICATION OF COSTING PROCEDURE . . . . . . . . . 5

PROFIT MAXIMIZATION . . . . . . . . . . . . . 7

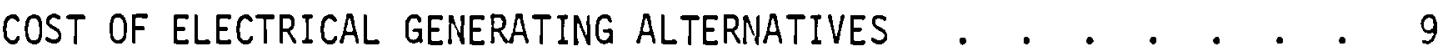

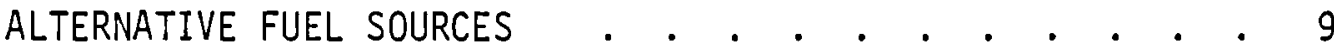

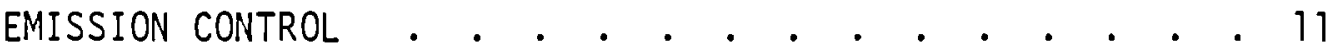

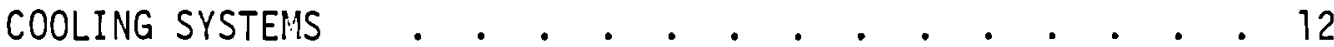

SITES . . . . . . . . . . . . . . . . . 14

ECONOMIC FACTORS . . . . . . . . . . . . . 15

TARIFF SYSTEM • • • • • • • • • • • • • • • •

REGULATION • • • • • . • • • • • • • • •

REVENUE REQUIREMENTS . . . . . . . . . • . . . 17

Rate Base . . . . . . . . . . . . . . . 18

Rate of Return . . . . . . . . . . . . 20

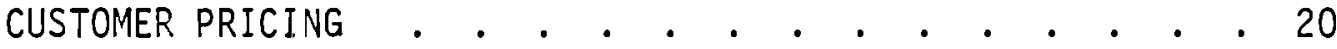

ALTERNATIVE PRICING SYSTEMS . • . . • • • • • . . 22

THE EFFECTS OF CAPITAL INVESTMENT DECISIONS ON THE RATE STRUCTURE 24 ECONOMIC INDEX . . . . . . . . . . . . . . . . 27

ATTRIBUTES • . . • . . . . . . . . . . . 27

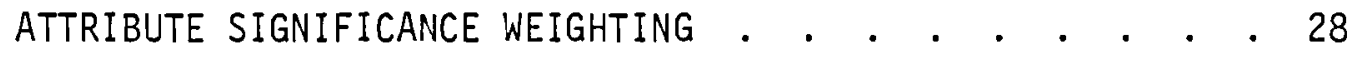

PARAMETER . . . . . . . . . . . . . . . . 29

SCALING . . . . . . . . . . . . . . . 31

SUMMARY . . . . . . . . . . . . . . 32

REFERENCES . . . . . . . . . . . . . . . . . 35

APPENDIX A: DERIVING WEIGHTS FOR THE ATTRIBUTES . . . . . A-1

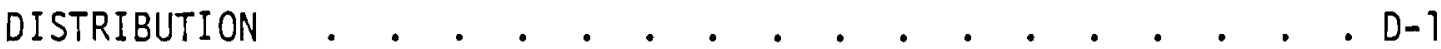




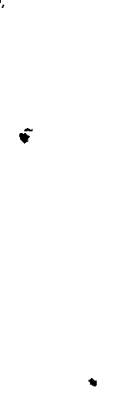




\section{$\underline{\text { LIST OF FIGURES }}$}

1 Private Market Cost Curves . . . . . . . . . . 3

2 Internalization of External costs . . . . . . . . 4

3 Load Duration Curve . . . . . . . . . . . 6

4 Profit Maximization for the Monopolist . . . . . . 8

5 Comparative Energy Costs at 75\% Capacity Factor (0\%

Annual Rate of Inflation). . . . . . . . . . 10

6 Total Generating Cost vs. Capacity Factors for a Large (2400 MWe) Baseload Units . . . . . . . . . 10

7 Weekly Load Curves . . . . . . . . . . . . 22

8 Economic Index . . . . . . . . . . . . . . 29

9 Residential Service for the Total Electric Utility Industry 30

10 Price of Electricity in the Northwest (Mills/kWh) (\$1975) 33

\section{LIST OF TABLES}

1 Average Use and Bi11/Consumer - Total Electric Utility Industry . . . . . . . . . . . . . . . . 24

2 Average Revenues/kWh Sold - Total Electric Utility Industry 25

3 Sales and Revenues/Customer, Revenues/kWh Sold, Tennessee Valley Area, Pacific Northwest Area, Other Areas . . . 26

A-1 Suggested Method for Rank Ordering and Weighting Attributes A-2 
6 
The purpose of this study is to develop a method for quantitatively determining the effect of new fossil fuel and nuclear electric generating facilities on the cost of power in the service region and local community. The resulting index of economic impact is intended for use in a methodology for assessing power plant site and design alternatives, currently being developed by Battelle, Pacific Northwest Laboratories for the U.S. Energy Research and Development Administration. The overall assessment methodology incorporates community values with technical assessments of impacts, providing a system for assessing preferred power plant site/design alternatives from the community's perspective.

Eight decision criteria were selected for the overall site assessment methodology:

- AESTHETIC: The general appearance of the plant and $i$ ts effect on the visual quality of the surrounding area.

- ECONOMIC: The effect of construction and operation costs on consumer power rates.

- WATER: The changes in the quality of nearby water bodies.

- LAND USE: The amount and kind of land taken by the plant; compatibility of area for plant construction and operation in relation to state, regional, and local land use planning.

- AIR: Effects on air quality.

- PLANT/ANIMAL: The effects on animals and plants, inciuding those in the air or water or on 1 and; effects on the ecosystem and food chain cycle.

- SOCIAL QUALITY: Potential effects on community structure and fiscal characteristics; potential effects on the historic resources and recreational opportunities of the plant site and surrounding area.

- EEALTH/SAFETY: Effects on human health and safety. 
A multi-attributed decision model of the following form is used to evaluate the overall "quality of 1 ife" resultinc from implementatior. of a power plant site or design option:

$$
c_{j}=W_{1} S_{1 j}+W_{2} S_{2 j} \cdots W_{i} S_{i j}
$$

where:

$C_{j}$ is an index of the quality of the community natural, social, and economic environment following implementation of povier plant site or design option $j$.

$W_{1}$ through $W_{8}$ represent the relative importance to the community of the decision criteria listed above.

$S_{1 j}$ through $S_{8 j}$ are measures of the quality of specific elements of the community natural, social, and economic environment, as defined by the decision criteria listed above.

Estimates of the effect of power plant site and design alternatives on each of the criteria are made by experts in the respective disciplines, . using assessment methodologies especially developed for the purpose. The system reported in this paper is one such system, for assessing the effects of power plant siting and design proposals on cost of electrical power in the service region. The product of each of these assessment methodologies $\left(s_{1}\right.$ through $\left.s_{8}\right)$ are measures of environmental quality, relative to the associated criteria. "Environmental quality" is used here in a broad sense, including social, economic, or natural elements as appropriate to the associated criterion.

For inclusion into the overall methodology each of the criteria indices ( $S$ 's) are expressed on a common interval scale of 0 to 100 where 0 represents an optimal level of quality and 100 represents a "worse case" level of quality. For example, in this study, optimal cost of power is based on the minimum rate experienced in the period 1965 through 1969 when electrical rates were stable, if not declining. For this condition, $S$ would equal zero. Effects of proposed power plant site or design options can be measured by comparing the "without-plant" condition to a projection of the "with-plant" condition. Comparisons can be made at the criterion 
level, or by use of the overall assessment methodology. Weights $H_{1}$ through $W_{8}$ are employed if the overall as sessment methodology is used. These weights are determined from responses of representative community residents and are indicative of the relative importance of the decision criteria to the community. Thus, the overall assessment methodology reflects community values.

The proposed system, like other structured decision systems for evaluating complex alternatives, should be considered advisory. It should be used in conjunction with other methods of assessment, such as engineering and economic evaluations; and the results should be intuitively correct to the decision makers. Perhaps more important than the indices resulting from application of this methodology, is the insight to the decision problem potentially gained by application of the assessment methodology. The purpose of the system is ncit to provide for rote selection of the al ternative having the best score, but rather to identify and understand comunity values and impacts of proposed electrical generating options to assist identification of preferred alternatives.

Other reports on this project have included:

1. J.B. Burnham, et al., A Technique for Environmental Decision-Making Using Quantified Social and Aesthetic Values, BNbL-1787, Battelle, Pacific Northwest Laboratories, Richland, Washington, February 1974.

The conceptual approach for this site assessment methodology; methods for determining the relative importance of each criterion to the affected community; an assessment methodology for aesthetic impact; and an examination of the land use criterion.

2. J.A. Hebert, M. K. Linde11, W.S. Maynard, S.M. Nealey, and J. B. Burnham, Socially Weighted Linear Composites in Environmental Decision Making, BNWL-B-467, Batteile, Pacific Northiest Laboratories, Richland, Washington, November 1975.

A discussion of the use of the weighted linear composite method for combining social values with estimates of impact. 
3. J.C. King, Social Values and Environmental Assessment in Thermal Power Plant Siting, BNW:L-SA-6065, Batte7le, Pacific Northwest Laboratories, Richland, Washington, February 1977.

A review of the decision methodology used to develop a comprehensive assessment of site and design alternatives.

4. R. E. Fitzner and K. L. Gore, A Quantified Decision Making Technique for Evaluating Impacts of Thermal Power Plants on Natural or Managed Biological Systems. BNWL-2226, Battelle, Pacific Northwest Laboratories, Richland, WA, September 1977.

The assessment methodology for impact on plant and animal life.

5. H.E. McGuire, Jr., The Effect of Liquid Waste Discharges from Steam Generating Facilities, BNWL-2393, Battelle, Pacific Northwest Laboratories, September 1977.

The: assessment methodology for impact on water quality. 


\section{INTRODUCTION}

Today, construction of a thermal power plant involves large capital investments at a time of high inflation, costly delays for environmental evaluation and licensing. The result is escalating plant construction costs and rising electric rates. The purpose of this paper is to assess the effects of plant construction, siting, and system design on consumer electrical rates.

To assess the social consequences of a monetary investment in al ternative power plant sites or designs, one must understand the economics of a regulated monopoly. The cost and profit maximizing procedures used by public utilities are reviewed and the tariff system is described. The tariff structure includes the rules, regulations, and rates governing a utility.

The costing methodology used by utilities was reviewed to determine the variables that affect the dollar differentials between site and design alternatives. Once busbar rates were established, the costs were followed through the utility system to the customer. The rate structure was reviewed with regard to theory and real world deviations. Probable changes in rates are discussed and effects on the consumers are suggested.

Finally, the possible effects of rate increase were incorporated into a subindex to allow comparison with other tasks. The subindex ranged from 0 to 100 with the higher value reflecting severity of impact. The attributes of the subindex consisted of residential, commercial and industrial consumers of the local area and of the service area. A weighting procedure was devised to distinguish the relative importance among the attributes by community representatives. Relative changes in electrical rates were the index parameter. The parameter was scaled based on historical and projected rate data. 
REVIEW OF COSTING AND ECONOMIC PROCEDURES

PRIVATE COSTS

Internal or private costs, such as capital or operating and maintenance, have a market price with defined ownership. The total private cost curve is the least total cost at which each quantity of output can be produced. The average cost is the per unit cost of production, or the total cost divided by total output. The marginal cost is the incremental cost of producing each additional unit or the slope of the total cost curve. In the short run, monetary resources are committed to fixed assets such as power plants and only costs such as fuel or labor are variable. In contrast, all costs are variable in the long run.

In the electric industry, average costs are expressed in mills/kWh. Fixed costs are capital costs expressed as $\$ / k W$. Historically, the electric industry has operated on the declining portion of average total cost curve (Figure 1) as a result of economies of scale, although the utility need not always operate under conditions of decreasing costs. For example, limited hydro capacity forced TVA to build steam power plants which increased per-unit production costs. (1) Environmental control measures, and licensing delays, which are very important in today's market, are having significant impact on the cost of power.

Figure 1 shows a set of hypothetical cost curves, which may not necessarily represent the electrical industry. However, as shown in figure 1 , the marginal cost curve is below the average total cost curve when average costs are declining, and intersects it when average total costs are minimal. In other words, average total costs equal marginal costs at the point of minimum average cost. This is important to note because the utility industry has historically been concerned with minimizing average total costs in pricing and costing. 


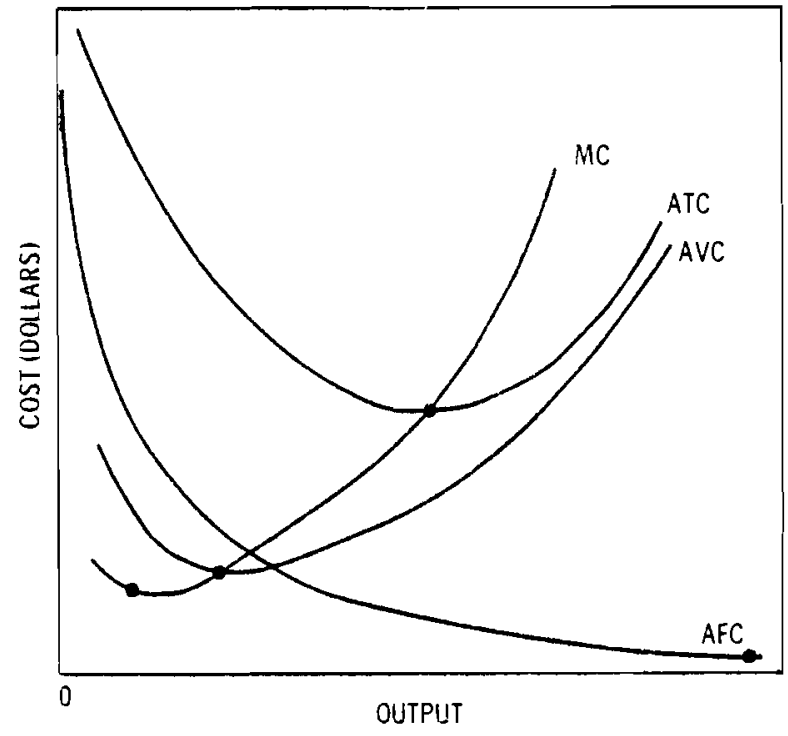

MC = MARGINAL COST

ATC = AVERAGE TOTAL COST

$A V C=$ AVERAGE VARIABLE COST

AFC - AVERAGE FIXED COST

FIGURE i. Private larket Cost Curves ${ }^{(2)}$

\section{EXTERNAL COSTS}

Those costs that lack an available market price are referred to as extra-market goods or externalities. Externalities associated with electricity generation include waste heat, radiation exposure, effluents from coal plants, etc. A private market supply curve does not account for any external cost or benefits. Theoretically when an externality is perceived by society to have a negative value, and is internalized by regulation, the supply function shifts to the left and becomes the marginal social cost curve instead of marginal private cost of supplying the commodity. The amount supplied would then decrease $\left(Q_{1}\right.$ to $\left.Q_{2}\right)$ to the point where marginal social benefits and costs are equal (Figure 2). The equilibrium point and quantity move to the left and decrease and the price of electricity increases to $P_{2}$. For example, if electricity generated in a thermal power plant and transmitted out of the area creates waste heat with negative impacts to the local population, most of the positive benefits of the electricity produced accrue to people who are not affected by the negative impacts. 


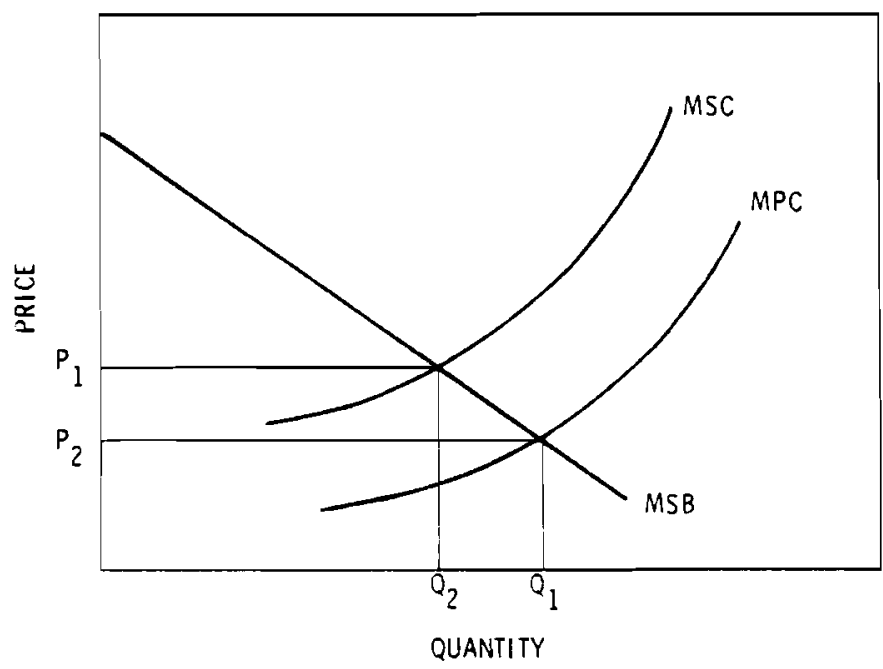

MSB = MARGINAL SOCIAL BENEFIT

MPC = MARGINAL PRIVATE COSTS

MSC = MARGINAL SOCIAL COSTS

\section{FIGURE 2. Internalization of External Costs}

The people not affected by the damages do not pay the marginal social cost of electricity unless the external costs resulting from thermal pollution are internalized. For example, the use of various cooling systems reduces waste heat released, thereby partially internalizing the externalities. This is why economists refer to costs as internal (private) and external cost, rather than economic and environmental costs.

Much attention has lately been given to efficient pricing schemes that equate social costs and price, which we will later discuss with alternative pricing in the tariff system section.

This paper considers private or internal costs of power generation including costs associated with plant systems designed to internalize externalities associated with mitigating environmental impacts. 
Generally utilities are vertically integrated; i.e., they own power plant transmission systems and distributing facilities. Some also own fuel sources and fuel transportation systems. (3) When assessing the costs of an additional generating unit for use in an economic index, one must consider how this addition will economically enter into the utility's total generating system.

To compare costs between alternative fuel sources, the power plant is typically analyzed independent from the system. In other words, the capital, operating and maintenance costs are estimated for onsite power generation. The average total costs (mills/kwh) of the new facility are referred to as the busbar rate. These estimates do not reflect transmission or distribution costs.

For a utility system, estimating the total cost curve, which is seldom if ever done, would involve various combinations of plants with different production costs and capacities. Remember, the total cost curve is the quantity produced for the least cost at each level of output, and average costs are per unit. - The addition of a plant to the system could increase decrease, or have no effect on the average total cost of electricity.

Plants of various capacities are built because demand for electricity fluctuates throughout the day and with the seasons. At certain times much of the capacity remains idle (this typically occurs during the early morning). Idle capacity is utilized however, during short intervals when most of the customers demand power. This is referred to as the peak load period.

Figure 3 shows a hypothetical load duration curve which illustrates the percent of time and type of power source a utility would use to meet the demand throughout the year. Peak capacity as shown in Figure 3 would be supplied by plants used for short intervals; these are plants with low fixed costs, high variable costs and rapid startup capability such as gas turbines. Intermediate plants are often older units that are not as cost effective to run because of higher operating or maintenance costs than the baseload plants. 


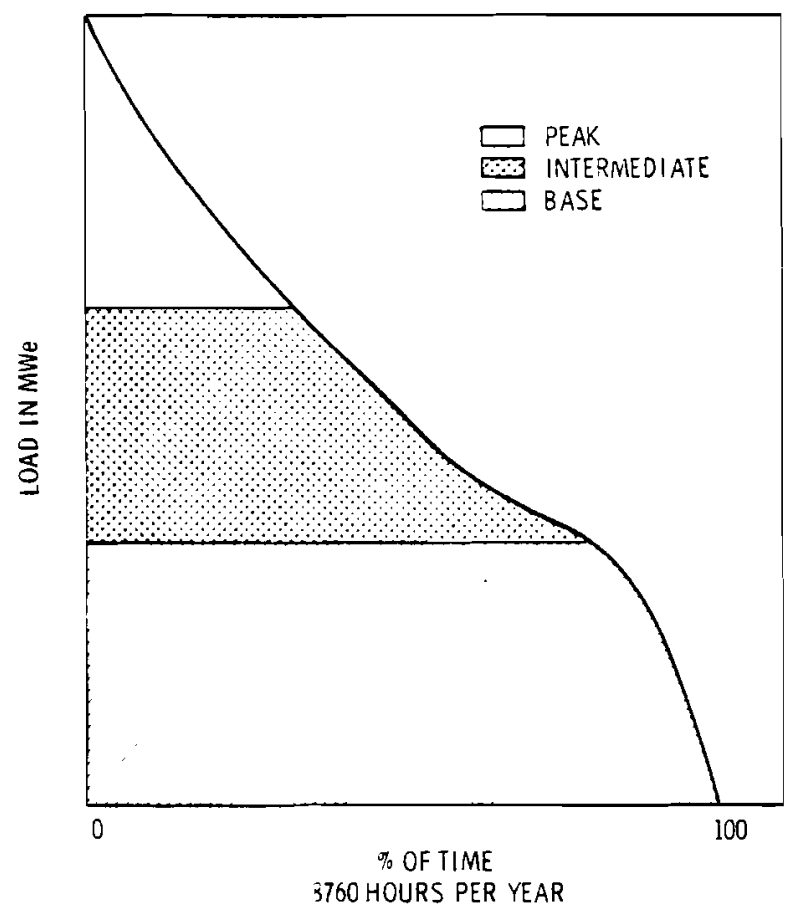

FIGURE 3. Load Duration Curve

The baseload plants are units with the lowest variable costs, and currently, the highest capital costs. Typically, large nuclear and coal units are built and operated for baseload capacity.

For purpose of later assessment with economic index, we will assume the utility needs baseload capacity. New baseload capacity typically involves new construction with large investments of capital which could have considerable impact on rate structure.

Currently, the fuels generally selected by electric utilities for baseload capacity are coal and nuclear. Many alternative fuels are technically available, such as solar, geothermal, natural gas, petroleum liquids, hydroelectric, and municipal solid waste. These alternatives are not currently chosen for commercial production by utilities for various reasons; i.e., lack of demonstration of baseload suitability, national policy, environmental regulations and unsuitable sites within the service area. We will, therefore, only consider coal and nuclear fuels in reviewing the framework of realistic decisions between alternative fuels. 


\section{PROFIT MAXIMIZATION}

Economic theory defines the pure monopoly as a market situation with a single seller of a unique product, without substitutes. In the real world there are few, if any, pure monopolies although public utilities come close. ${ }^{(4)}$ some public utilities are even considered natural monopolies because of the capital intensive nature of these industries. It is thought that direct competition would result in diseconomies from unnecessary duplication in capital investment. (1)

In a theoretical situation, maximum profits for both the monopolist and the pure competitor result from the greatest difference between the total cost and total revenue. Total revenue is quantity sold times the seling price. In incremental or marginal units, profit maximization would occur where marginal cost equals the marginal revenue, where marginal costs are increasing. The difference between the competitor and the monopolist is the marginal revenue curve.

For a private market good such as electricity, there is an inverse relationship between the price and quantity demanded; at higher prices, quantities demanded are lower. Factors influencing individual demand include income, preferences, price of other goods, substitutes, and expectations. A monopolist's demand curve is the market demand, the quantity produced determines the price, therefore, the more produced the lower the price. In a competitive situation, individual producers face the market demand curve which is the marginal revenue curve. The individual can only affect total revenue through quantity sold. Unlike the competitor, the monopolist's marginal revenue decreases with each unit sold. Therefore, as shown in Figure 4 , the demand is greater than marginal revenue. Profit maximization still occurs at the intersection between marginal revenue and marginal cost, so $X$ units are produced. Profits occur in the shaded area above the marginal cost. In a competitive market the marginal revenue curve is the demand curve and production would occur at $X_{1}$ where marginal costs equals the demand. We can see that the monopolist also limits production by producing $X$ rather 


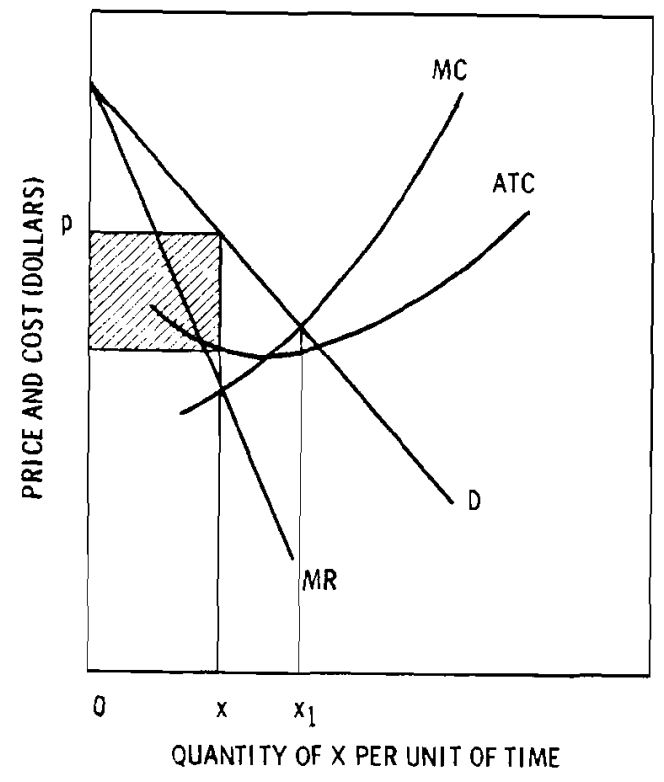

FIGURE 4. Profit Maximization for the Monopolist(2)

than $x_{1}$. In the real world when monopolies exist, they are regulated because of their ability to make pure profits and limit production. This is discussed in terms of the electric industry in a later section. 


\section{COST OF ELECTRICAL GENERATIMG ALTERNATIVES}

This section will discuss the fuel sources and other design options currently available for baseload capacity. Fuel, emission control and cooling system alternatives will be reviewed in terms of costs and technical feasibility. Sites and economic parameters are also considered in terms of their effects on cost of eiectricity for later use in the economic index.

\section{ALTERNATIVE FUEL SOURCES}

A typical approach for comparing costs of fuel alternatives is to categorize costs into capital, operating and maintenance. These costs are then levelized (annualized) over the life of the plant and valued in the dollars of the year the plant comes on-line. Figure 5 illustrates capital, operating, and maintenance costs of a power plant at $0 \%$ inflation (1976 dollars). Figure 6 shows costs estimated for various capacity factors in

Oklahoma. (6) Typically capacity factors are assessed in a range of $50 \%$ to $80 \%$. Contributing to the need for a range evaluation has been the poor performance of some large nuclear and coal plants in the past, and expected improvements in technologies over the next 30 years. This would lead one to expect today's baseload plant to be replaced by a more efficient plant and operate in intermediate capacity during the later years of generation. It is further expected that startup delays will occur during the first few years of operation. (5)

At first glance, coat appears attractive as a fuel source because of the large U.S. reserve (estimated at 434 billion tons), (7) and low capital costs. However, from the utility's standpoint several problems need to be considered. First, there are geographic dislocations of coal resources. Much of the coal is located in the West, which would involve costly transportation to eastern utilities. Secondly, air quality standards and regulations for suifur emission limit a utility to three control options; using low-sulfur coal, pollution control processes and equipment, and siting considerations. Emission controls and coal transportation contribute to the relatively high variable costs of coal-fired generating plants. 


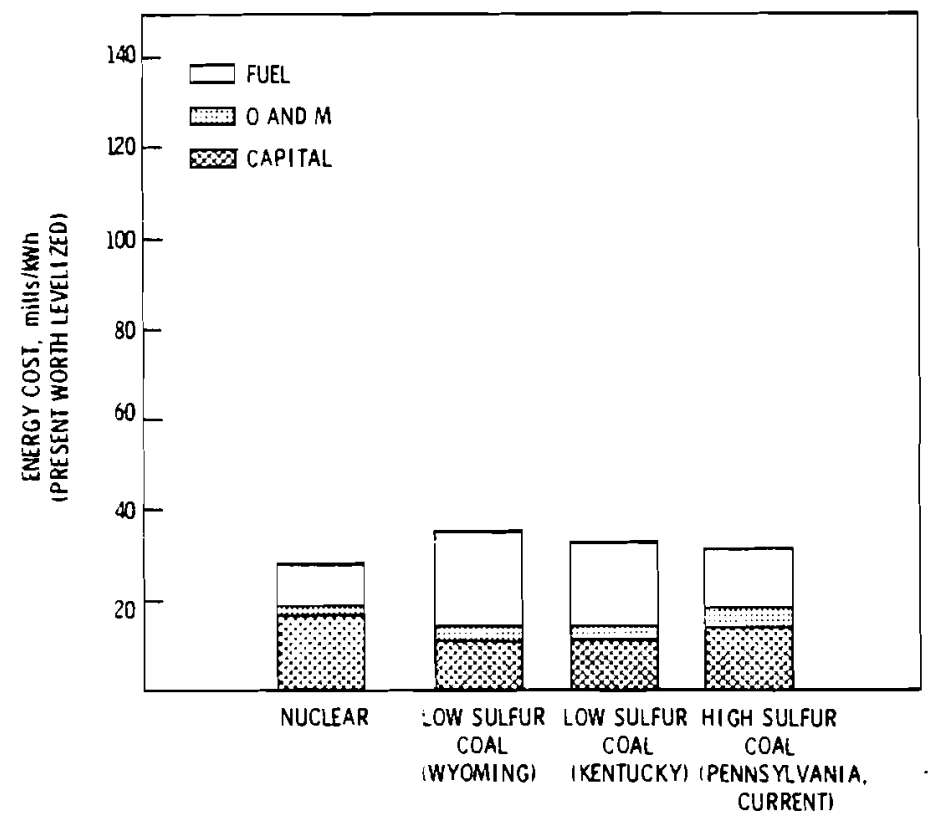

FIGURE 5. Comparative Energy Costs at $75 \%$ Capacity ${ }^{(5)}$ Factor ( $0 \%$ Annual Rate of Inflation)

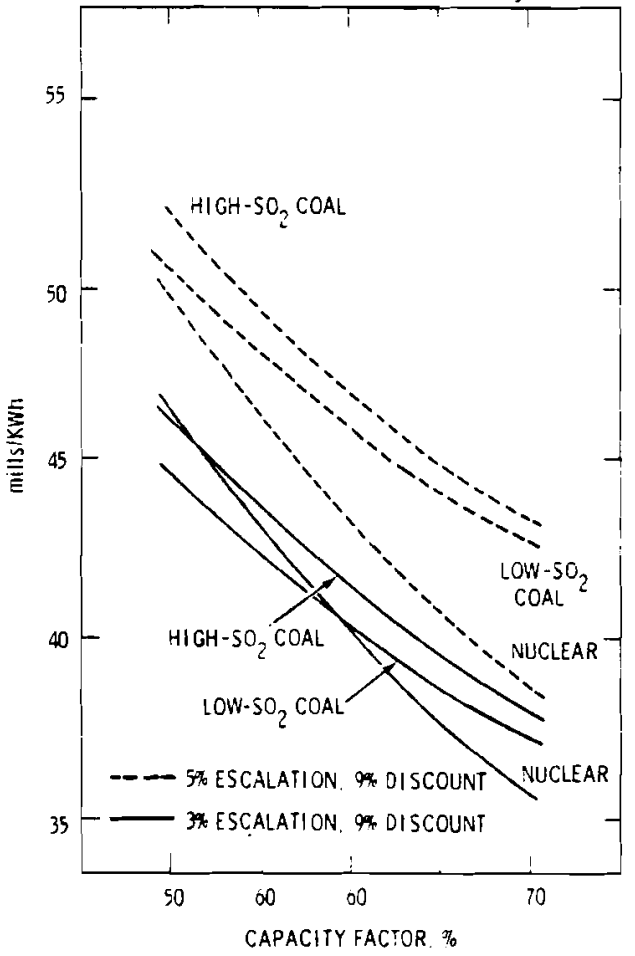

FIGURE 6. Total Generating Cost vs. Capacity Factors for a Large (2400 MWe) Baseload Units (6) 
Likewise, nuclear generation has certain benefits and costs that must be considered. Capital or fixed costs for nuclear power plants are significantly higher than coal plants, although operating and maintenance costs are low enough so that nuclear plants are competitive with coal plants.

\section{EMISSION CONTROL}

Concern for public health and welfare has resulted in regulations that reduce the amount of sulfur oxides released to the atmosphere from coal combustion. Externalities associated with $\mathrm{SO}_{2}$ include generation of acidic aerosols, inhalation hazards for humans, and possible aesthetic impacts of reduced visibility and plumes.

Emission controls include use of low-sulfur coal or pollution control processes; i.e., scrubbers, tal1 stacks.

Most of the low-sulfur (subbituminous and lignite) coal is located in the West. This type of coal has a low Btu output which increases the amount of coal required to fuel a plant which further increases transportation costs. As a result, recent trends in the west have been to locate coalfired facilities at mine-mouths so little or no transportation is required. (7) This, of course, assumes transmission costs are not a limiting factor. Because of the large amounts of low-Btu coal required to fuel a plant, an additional problem arises in that EPA pollutant emissions standards cannot always be met.

Low-sulfur, high-Btu coals in eastern regions command a relatively higher price which makes them noncompetitive for electric generation at this time. However, eastern coals with both high-Btu and high-sulfur content are typically cost competitive, al though air quality regulations and standards require the utility to remove the sulfur by control devices.

Limestone and lime wet scrubbing process are currently the most widely used and highly developed flue gas desulfurization methods for sulfur removal. It is expected that over $90 \%$ of high $\mathrm{SO}_{2}$ coal plants will be controlled by limestone or lime scrubbing by the end of 1977 . Problems associated with wet scrubbing include process unreliability, 
high capital and operating costs, and disposal of a large quantity of waste sludge. ${ }^{(5)}$ The capital cost estimate for scrubbers in 1975 dollars ranged from $\$ 60 / \mathrm{kW}$ to $\$ 80 / \mathrm{kW}$. ${ }^{(8)}$ Figure 5 illustrates this higher capita 1 and operating cost associated with high-sulfur coal. Also shown are the high fuel costs of low-sulfur coal that reflect high transportation penalties. (5)

Other methods of sulfur removal not categorized under flue gas desulfurization include supplementary control systems (SCS). The EPA defines SCS as "an acceptable control measure only in cases where constant emission reduction measures are unavailable and only until such measures become available."(8) Typically, these methods meet EPA standards by reduced electrical production or by shifting fuels. The type of system varies in terms of components and detail. TVA is probably the most wel1 known proponent of SCS in the electrical industry. Twelve large TVA coalfired plants use SCS (tall stacks) which amounts to $72 \%$ of installed TVA capacity. The cost effectiveness of SCS systems compared to $\mathrm{SO}_{2}$ scrubbers range from a factor of 10 to 100 depending on the plant.

\section{COOLING SYSTEMS}

For a nuclear power plant, the most significant design decision in terms of dollars is the cooling system. Included in the cooling system are environmental protection facilities that prevent or reduce externa] damages attributable to waste heat discharge, such as drift and fogging, or damage to ecological species. There are many alternative cooling systems available including mechanical draft towers, dry cooling, natural draft towers, cooling lakes, spray canals, and once-through cooling, al though some may not be environmentally viable at certain sites.

For once-through cooling, water is circulated through the steam condenser and returned directly to the original body of water. This system seldom meets waste heat discharge regulations and as a result, is only used for plants near large bodies of water. ${ }^{(6)}$ At one time, oncethrough cooling had significantly lower costs although increased environmental regulation has reduced the cost differential between once-through 
and other cooling systems. (11) Even still, this cooling mode is usually lowest in cost. (11)

Evaporative cooling towers use mechanical or natural draft to provide cooling by evaporation and sensible heat transfer. The externalities of both mechanical and natural draft include fogging and icing in a local area (generally on or near the site). Natural draft towers are large structures with plumes that could be aesthetically displeasing; ${ }^{(12)}$ while mechanical draft systems, al though physically less imposing, may produce noise from fan operation. Mechanical draft has lower capital costs than natural draft but it requires electricity during operation. The electricity consumed in operating is referred to as a "penalty," although it is eventually valued as the opportunity costs of electricity. The busbar cost for mechanical draft is generally lower than natural draft.

A cooling pond is essentially a heat sink; it is economical and effective in certain sites. The major constraint to cooling ponds is the availability of level land at a competitive price. Approximately 2000 to 3500 acres are needed for a pond large enough to c00l a 2300 MW plant. (6) Spray canals reduce the pond size about 20 times; the spray module dissipates heat to atmosphere through evaporation and conduction. ${ }^{(6)}$ To date there has been only limited experience with spray canals. Thus, environmental and economic data are limited. Cooling ponds and spray canals are very site-specific in terms of costs, although in some instances they are competitive with other cooling systems.

The capital costs of commercial cooling systems have been estimated as high as $\$ 20$ million; a substantial amount of capital, but a small portion of the total capital costs of the plant (about $2 \%$ ). ${ }^{(9)}$ As a result, the selected mode of cooling is not significant in terms of average cost of electricity (mills/kWh) but in actual costs the selected system is significant. $(9,10)$ However, costs of cooling system environmental protection devices should be compared to the value of the prevented damage to the environment. 
Certain economic factors enter into site selection criteria after the busbar rates have been estimated. Economic factors include costs of transmission, distribution and fuel transportation.

Energy transmission can be an important criterion for site selection for both coal and nuclear alternatives. Because of the tendency to site nuclear plants in areas of low population density and coal plants at minemouths, transmission costs can be considerable. The utility must not only estimate the physical cost of transmission facilities but also the loss of electricity (line loss). For a coal plant, a utility would consider the tradeoffs between transporting coal and transmitting electricity. In contrast, nuclear fuel transportation costs are relatively minimal and are not a part of site selection decisions.

Various factors in coal transportation need consideration; for example, loading coal is relatively expensive when compared to transporting coal. Thus, it is not cost effective to transport coal short distances. The recent trend toward mine-mouth coal plants in the west reflects this factor. An example of economics of transportation is the estimated cost comparison between mine-mouth generation in Wyoming or Montana versus transporting coal to western Washington to generate power for the SeattleTacoma area. Power costs were estimated to be $50 \%$ less from transporting coal, compared to mine-mouth generation. (12) However, the regulation on effluent emissions forces coal plants away from some large load centers like Los Angeles. Thus, the proposed Colstrip plants in Wyoming and the Four Corner plants operating in Utah, which supply the Los Angeles area with electricity, are being built and operating. However, there has been significant opposition in several Rocky Mountain states to coal plant siting.

It is probable that nuclear and coal plants would not both be chosen by a utility for the same area. For example, coal may be located closer to population centers or at a mine-mouth. When considering transmission and distribution costs, the comparison between alternative sites becomes 
complex; i.e., associated with each site would also be alternative transmission lines with different costs and penalties.

Site-specific costs unique to the actual power plant location need attention, although these are not as significant in the site selection process. These private costs include system design alternatives such as cooling facilities, transportation networks, etc. Extra-market costs usually include environmental damages and socioeconomic costs.

In addition to economic considerations, various regulations and institutional constraints limit the utility in site selection. Areas such as parklands, wilderness areas and historical sites are avoided. Nuclear sites are sensitive to population densities, meteorology, geology, seismology, and water flows. Coal sites have less rigid environmental constraints but are also vulnerable to many above factors, particularly emissions to the atmosphere.

\section{ECONOMIC FACTORS}

When estimating costs for thermal power plant sites and design alternatives, certain economic factors become significant. Because power plants are capital intensive, inflation rates and cost of money become major factors in private costs of electrical generation. Predicting inflation and interest rates for ten years into the future is difficult during plant construction. This is true especially for today's rising prices. Variable costs are also difficult to estimate for plants coming on-line in 10 years and operating over 30 to 40 years. Inflation rates and cost of money are even more difficult to estimate for 40 to 50 years from the date of the cost estimate.

Variable costs are very complex, especially with the uncertainty associated with fuel supplies for both nuclear and coal alternatives. Government regulations can further add to uncertainty of total cost estimates by requiring additional environmental and safety improvements. Additional regulations not only increase capital and operating costs, but can also delay construction. Construction delays are becoming a major reason for rising power costs. 
Figure 6 illustrates the importance of escalation and capacity factors in determining the advantage between alternative fuel sources for nuclear and coal plants located in OKlahoma. At a capacity factor of $50 \%$ with a relatively low escalation rate, both high- and low-sulfur coals are more cost effective than nuclear. At a high escalation rate of $5 \%$, nuclear is the preferred fuel.

Regional cost differentials occur for construction and operation of both nuclear and coal plants. Factors contributing to cost variance throughout the country include labor costs (wage rate, productivity) coal supplies, state environmental regulations and standards.

Figure 5 provides an example of the effects of new construction on electricity rates. These estimates are based on zero inflation which provides us with an indication of current average costs of construction, if construction time was only one year. Busbar costs of power, as shown, range from $27 \mathrm{mills} / \mathrm{kWh}$ to $35 \mathrm{mi} 1 \mathrm{~s} / \mathrm{kWh}$. Using these estimates in New York, electricity costs were lowest for the nuclear alternative and highest for the low-sulfur western coal. 


\section{TARIFF SYSTEM}

\section{REGULATION}

Because monopolists under certain conditions have the ability to make pure profits and limit output, they are regulated by the government. Social control of monopolies avoids unduly discriminating rates and assures adequate service. (14) Statutes authorize controls over revenues, security issues, pricing practices and service standards. (14) Service standards include a capacity obligation and a designated service area. An electric utility is legally obligated to supply all electricity demanded at the administered price. This involves projecting future loads and providing needed capacity. Service areas are established and maintained within geographic boundaries which limit the utilities' expansion or growth to the economic activity within the service area. This is an important consideration for a utility in that the price of electricity can affect the attractiveness of an area for industrial growth. Thus, rate structures are sometimes designed to attract industry to the service area.

\section{REVENUE REQUIREMENTS}

Regulation of a monopoly generally takes two forms - price ceilings and taxation. The standard regulation for electricity utilities is the price ceiling. The price or rate of electricity is administered by a state regulatory authority. Historically, the utility industry has been required to maintain "just and reasonable" rates. (13) The "just rate" has been typically characterized by the approximate cost of the delivered power. This approximate cost has been some form of average cost pricing. This pricing system is the most common used in nearly all states. (3) Average cost pricing is seldom the simple economic definition of total cost divided by total output. In the real world, a utility's "average cost pricing" usually equates total cost to total revenue. Revenue requirements are the estimated revenues needed to cover future total costs, plus a fair return on investment. A typical formula for revenue requirement is shown below. (6) 


$$
R R=E+d+T+(V-D) R
$$

where

$$
\begin{aligned}
R R & =\text { revenue requirement } \\
E & =\text { operating expenses } \\
d & =\text { annual depreciation expense } \\
T & =\text { taxes, including income taxes } \\
V & =\text { gross valuation of the property serving the public } \\
D & =\text { accrued depreciation } \\
R & =\text { rate or return (a percentage) } \\
(V-D) & =\text { rate base (net valuation) } \\
(V-D) R & =\text { return or profit, expressed as earnings allowed on the rate } \\
& \text { base. }
\end{aligned}
$$

Revenue requirements are determined in the Public Utility Commission hearings. The usual approach taken is use of the historical base which is quite often the preceeding twelve months. This historical base is referred to as the "test period" or the "test year". The test year is normalized if any unusual conditions have occurred such as unseasonable weather. The purpose of this process is to estimate revenue requirements in the near future which will result in the utilities attracting capital at a rate which is reasonable. The revenue requirement process has had reasonable success in the past, which contributes to its wide acceptance. The utility industry had been experiencing stable prices, if not decreasing prices due to improvement in productivity. (15)

Two critical factors in the above formula, which have received considerable attention, are the rate base and the rate of return on inves tment.

\section{Rate Base}

The rate base is the value of the company's property minus incurred depreciation. Determination of the rate base is a difficult problem in that items included in the rate base and the value of those items included are debatable. (6) 
Because of the regulated nature of the industry, utilities have had the incentive to maximize the rate base to increase revenue requirements. In contrast, consumer representatives have tried to minimize the rate base in an attempt to reach a just and reasonable price for electricity. (15)

Items typically included in the rate base are tangibles; i.e., land, buildings and equipment. Items excluded from the rate base by the comission are: 1) duplicate and unnecessary property, 2) obsolete and inadequate property, 3) property to be abandoned, 4) abandoned and superceded property, 5) overdeveloped property and facilities for future needs, 6) real estate, buildings, leaseholds and water rights, 7) incomplete and contemplated construction, 8) property used for nonutility purposes, 9) property for other utility departments, 10) property not owned, 11) property donations, voluntary or involuntary, and 12) deposits and money advanced by customers. Items excluded from the rate base that have particular importance to this study include contemplated construction and ongoing construction activities. In other words, the effects of a new facility on the rate base would not occur until operation. We will, therefore, assume construction is complete and the time frame considered will be the first year of operation. It should be noted although that allowing construction costs into the rate base has been a major conflict, and a few commissions would allow part of the expenses of construction into the rate base. Usually expenses allowed into the rate base are limited to interest or some portion of interest during construction.

After the $i$ tems included in the rate base have been established, a problem of measuring the value of these items become apparent. The value of the property in a competitive situation is a market value; whereas under regulation, the utility assesses property at a fair value. Some costs are a function of a number of customers, or energy production but the bulk of the costs are a function of capacity. Capacity-related costs have been difficult for commissions to handle and, therefore, are not assessed in the rate structure. (15) For example, the average cost of maintaining peak capacity is greater than average cost of baseload capacity. 


\section{Rate of Return}

The rate of return is the second factor in the revenue requirement under considerable scrutiny. There is a significant amount of discussion on what "a fair rate of return" should be by the Public Service Commission, utilities, and economists; each has a different viewpoint. Although an interesting area, the question of what is a fair rate of return is beyond the scope of this project and not directly related. Therefore, beyond noting that there is considerable literature available on this topic, $(1,14)$ we make no conclusions on what is the correct approach to determine the fair rate of return on investment.

\section{CUSTOMER PRICING}

Once the revenue requirement is established, the utility needs to estimate total revenues for the next year. Generally, the total revenue is price times quantity or rate times sales for each customer class. The price of electricity is inversely related to the quantity/demand, and the response to demand from a price change is referred to as price elasticity. When considering the price increase, the price elasticity should also be considered in order to estimate the effect on future sales.

The ease with which the buyer can substitute an alternative fuel will affect the demand for electricity. That is to say, the more elastic the demand, the more readily substitution can occur. If a monopolist can separate customers and market classes based on different demand elasticity, then he can price discriminate. ${ }^{(a)}$

Those market classes with less elastic demand curves will pay higher prices rather than substitute. For example, a large industrial customer may have several fuel options available such as coal, oil, natural gas; however, the residential customer has few substitutes for electrical

(a) Price discrimination, as defined by the economist, is selling the same commodity to different groups at different prices. 
lighting. Economic theory suggests that the profit maximizing monopolist would discriminate and charge higher prices to the residential customers regardless of the cost of delivered power.

In the utility, industry rates do vary with customer classes, but this is referred to as "price differentiation." Under regulation, utilities rationalize price differentials based on variance in costs of supplying power. A typical breakdown of market classes consists of: 1) resideritial, 2) commercia 1, 3) large industrial, 4) farm, 5) street and area lighting, and 6) government and miscellaneous. (3) cost differential depends on distribution systems, quantity use, time of use, etc. Even though the customer price is supposed to reflect the cost of supplying power, problems do arise because it is sometimes difficult or even impossible to determine the actual cost of delivered power for a market class, let alone an individual customer. When customer pricing does not reflect the cost of producing, then price discrimination occurs; considered by the commissions as socially undesirable. (a)

It was found by utilities that economics in distribution facilities could be realized if the customer utilized capacity at a higher load factor. ${ }^{(2)}$. This resulted in rate structures having lower rates for higher consumption. Customers found this very attractive and accepted these rates readily. However, in recent years of environmental concern and energy scarcity, promotional pricing has been discouraged.

For our purposes, it is important to understand customer classes to determine how utilities will allocate a rate increase. Economic theory suggests those customers with the less elastic demand will pay a higher rate. In the real world, it is not clear that this occurs because of regulations and rules governing utilities under an average cost pricing sys tem. (a) Price discrimination, as denoted by electric industry, is charging
customer rates not reflecting the cost of delivering the power. 


\section{ALTERNATIVE PRICING SYSTEMS}

The load pattern as shown in Figure 7 reflects the incentive of average cost pricing. The most substantial pattern established as a result of average cost pricing is seasonal and daily peaks. Air conditioning is the principal contributor to a differential between summer and winter loads. Nationally, the load factor averages only about $65 \%$. (15) As illustrated in the load duration curve (Figure 3 ), utilities can and have responded to the peak demand in a relatively efficient manner.

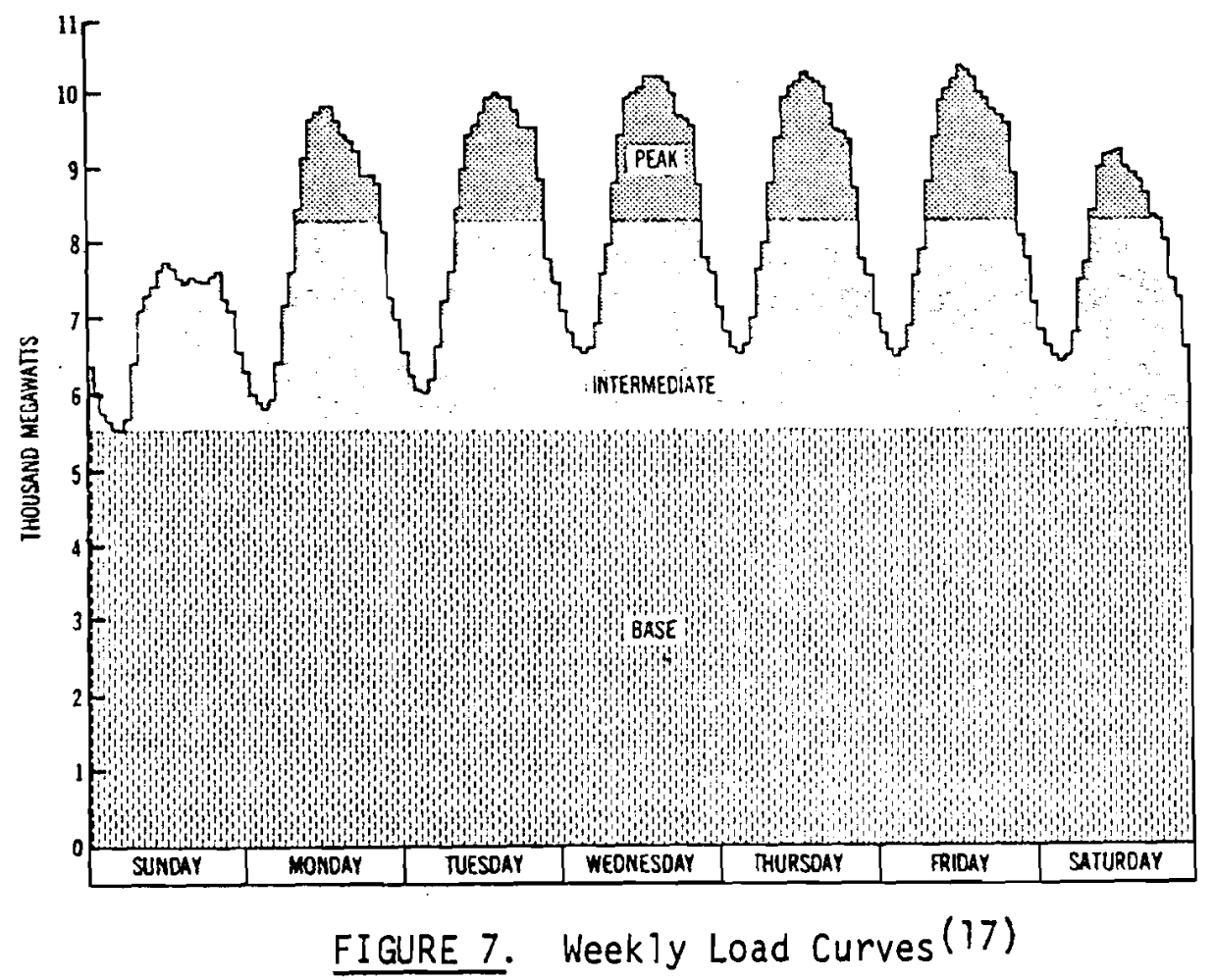

The accuracy of the revenue requirement process in estimating future needs has been questionable in the past few years. The utilities are currently faced with a revenue pinch, constraining their ability to finance new plants and replace older generating facilities. The traditional regulatory lag in rate approval has been imparing revenues, rates of return, and profits. (16) The cost of electricity is currently rising 
because of inflation, fuel shortages, and ervironmental requirements. Unit costs are rising because of economies of scale and technological improvements are not offsetting the costs of new plants. This means that new plants coming on-line will increase average costs unless more capacity is utilized and peak demand reduced.

The many problems associated with average cost pricing has focused attention on alternative rate structures. Alternative rate possibilities are numerous, including such pricing schemes as capacity-only, energyonly, marginal costs, long-run incremental costs, inverted rates and 1 ifeline rates. (3) These alternatives have been proposed by various disciplines ranging from the utility analyst to the academic economist. What is sought in an alternative system, not found in the historical system, is the incentive to reduce peak demand. Thus, improving load factors and reducing capacity requirements; which in the rear future, would reduce the need for new plant construction. Eventual capacity expansion would be mainly in the form of baseload, operating at a higher capacity factor and, therefore, high efficiency. (16) It is likely that new pricing schemes will be implemented throughout the industry. In fact, several utilities have already adopted al ternative systems. 
In 1975, the average residential customer of privately-owned utilities consumed $7,829 \mathrm{kWh}$ at an average rate of $3.51 \mathrm{k}$, which amounted to an annual bill of $\$ 275.20$. Electrical rates for industrial customers was $2.08 \$ / \mathrm{kWh}$, and $3.46 \mathrm{k} / \mathrm{kWh}$ for commercial customers of the privately-owned utility. (18) For the total electric industry (both private and public utilities), the average rate was $3.21 \% / \mathrm{kWh}$ for residential customers in 1975 , as shown in Table 1. Also shown in Table 1 is the kWh consumption for 5-year intervals for residential and commercial customers along with the average annual bill per customer. (19) As shown in Figure 5 , estimated costs of new generation facilities ranged from $27 \mathrm{mills} / \mathrm{kWh}$ to $35 \mathrm{mills} / \mathrm{kWh}(2.7 \mathrm{k} / \mathrm{kWh}$ to $3.5 \phi / \mathrm{kWh}$ ) for plants brought on-line today. $(5)$ The range reflects the various fuels and design systems. Without considering transmission and distribution costs, these estimates compare favorably with national average rates.

TABLE 1. Average Use and Bill/Customer -
Total Electric Utility Industry (19)

\begin{tabular}{|c|c|c|c|c|c|c|c|}
\hline \multicolumn{4}{|c|}{ Average Kilowatt-Hours Used Per Customer } & \multicolumn{4}{|c|}{ Average Annual Bill Per Customer } \\
\hline Year & Residential & $\begin{array}{l}\text { Commercial } \\
\text { (Sma il Light } \\
\text { and Power) }\end{array}$ & $\begin{array}{c}\text { Total } \\
\text { l'itimata } \\
\text { Custoners' }\end{array}$ & rear & Residential & $\begin{array}{l}\text { Commercial } \\
\text { (Smal1 Light } \\
\text { and Power) }\end{array}$ & $\begin{array}{c}\text { Total } \\
\text { Ultimate } \\
\text { Customers }\end{array}$ \\
\hline $\begin{array}{l}1975 \\
1974 \\
1973 \\
1972 \\
1971\end{array}$ & $\begin{array}{l}8,176 \\
7,997 \\
8,079 \\
7,697 \\
7,830\end{array}$ & $\begin{array}{l}48,964 \\
46,557 \\
47,580 \\
44,496 \\
47,943\end{array}$ & $\begin{array}{l}21,417 \\
21,448 \\
21,955 \\
20,964 \\
19,956\end{array}$ & $\begin{array}{l}1975 \\
1974 \\
1973 \\
1972 \\
1971\end{array}$ & $\begin{array}{r}\$ 262.45 \\
223.77 \\
192.28 \\
176.12 \\
161.62\end{array}$ & $\begin{array}{r}\$ 1,582 \\
1,327 \\
1,094 \\
988 \\
889\end{array}$ & $\begin{array}{r}\$ 578.26 \\
493.30 \\
408.36 \\
371.06 \\
337.26\end{array}$ \\
\hline
\end{tabular}

(a) Total ultimate customer is the average of all customer classes. 
However, transmission and distribution costs can be considerable, especially if long distance transmission capacity is required. The line loss also needs to be assessed. If we consider for demonstration purposes that transmission costs increase average costs $20 \%$ and $50 \%$, then we have estimates that range from $3.2 \phi / \mathrm{kWh}$ to $4.2 \phi / \mathrm{k} W \mathrm{~h}$ and $4.0 \phi / \mathrm{kWh}$ to $5.25 \mathrm{c} / \mathrm{kWh}$. The comparison with current average costs is not quite as favorable.

How the cost of new power will be allocated across price structure is not clear. However, the differential in customer pricing on a national scale can be viewed from Table 2. Particularly noticeable are the lower rates paid by large light and power customers.

TABLE 2. Average Revenues/kWh Sold -

Total Electric Utility Industry

Cents Per kilowatt-Hour

\begin{tabular}{|c|c|c|c|c|c|c|c|}
\hline Year & Residential & $\begin{array}{l}\text { Commercial a: } \\
\text { Smal1 Light } \\
\text { and Power }\end{array}$ & 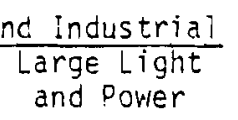 & $\begin{array}{l}\text { Street \& } \\
\text { Highway } \\
\text { Lighting }\end{array}$ & $\begin{array}{c}\text { Other } \\
\text { Public } \\
\text { Authorities }\end{array}$ & $\begin{array}{l}\text { Rail roads } \\
\text { and } \\
\text { Railways }\end{array}$ & $\begin{array}{c}\text { Total } \\
\text { Ultimate } \\
\text { Customers }\end{array}$ \\
\hline $\begin{array}{l}1975 \\
1974 \\
1973 \\
1972 \\
1971\end{array}$ & $\begin{array}{l}3.21 \mathrm{c} \\
2.83 \\
2.38 \\
2.29 \\
2.19\end{array}$ & $\begin{array}{l}3.236 \\
2.85 \\
2.30 \\
2.22 \\
2.12\end{array}$ & $\begin{array}{l}1.926 \\
1.55 \\
1.17 \\
1.09 \\
1.03\end{array}$ & $\begin{array}{l}4.746 \\
4.31 \\
3.83 \\
2.69 \\
3.53\end{array}$ & $\begin{array}{l}2.24 \zeta \\
1.92 \\
1.47 \\
1.37 \\
1.29\end{array}$ & $\begin{array}{l}3.72 t \\
3.43 \\
2.20 \\
1.92 \\
1.72\end{array}$ & $\begin{array}{l}2.70 c \\
2.30 \\
1.86 \\
1.77 \\
1.69\end{array}$ \\
\hline
\end{tabular}

Another consideration is that the national average rates are not entirely representative of all regions in the country, particularly for the Pacific Northwest and TVA utilities where customers pay significantly lower rates as shown in Table 3. ${ }^{(20)}$ Increased system cost for new generating facilities would be significant in these areas. 

TABLE_3. Sales and Revenues/Customer, Revenues/kWh Sold, Tennessee (20)
Valley Area, Pacific Northwest Area, Other Areas 1

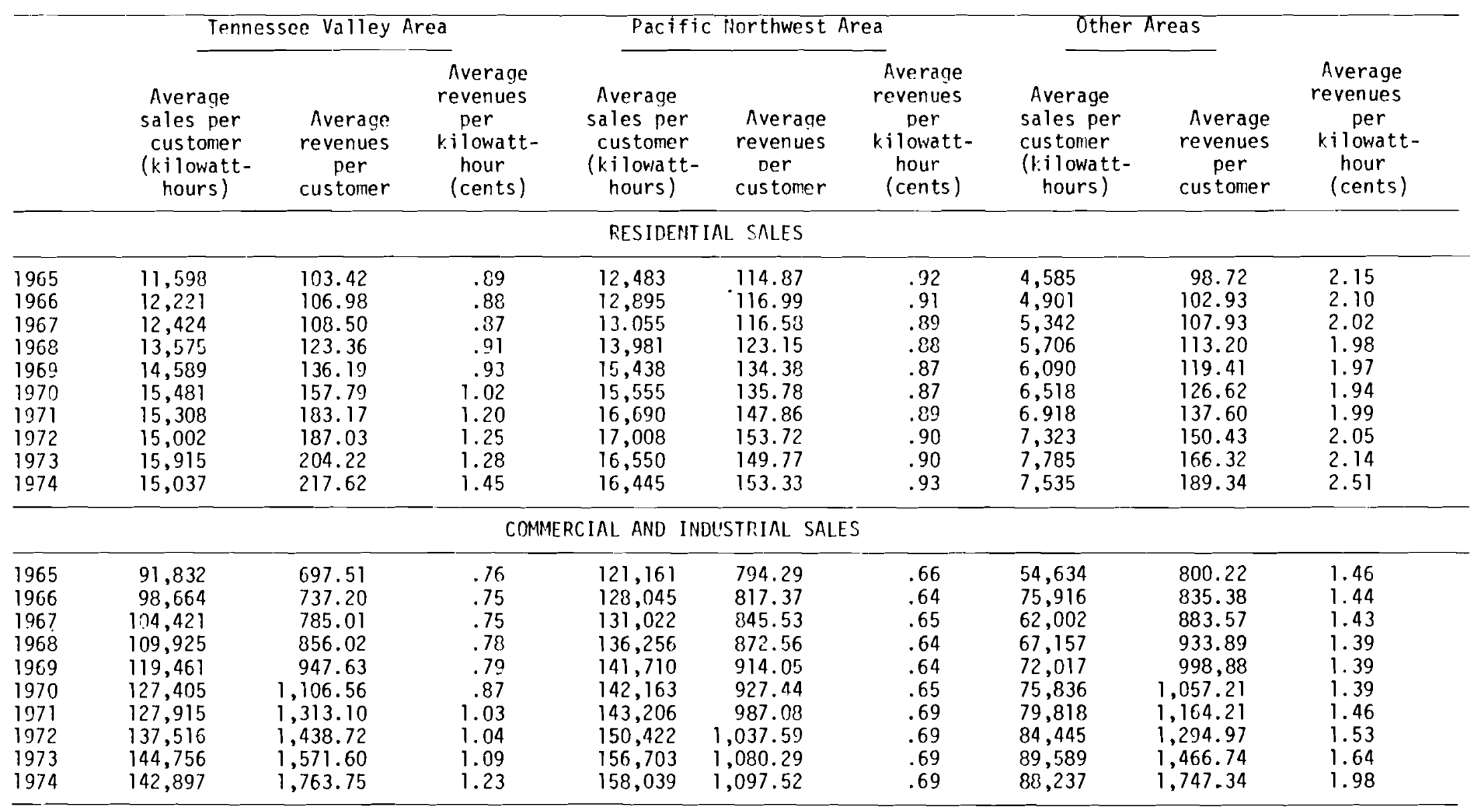

1Exclusive of the Power Authority of the State of New York. 
A multiattributed decision index has been developed to incorporate the effect of power plant site or design alternatives on the cost of delivered power to the consumer. This index will be used as a subindex for the comprehensive index $\left(C_{j}\right)$ that includes the eight criteria described in the Foreword. The economic index $\left(S_{e}\right)$ is composed of six attributes. The rate or price of electricity is the basic parameter of the index. The final $S_{e}$ value is estimated by scoring the parameter and multiplying the weighted attributes and summing the results.

For comparison purposes, the use of an index to measure a private market good already valued in dollars may not appear appropriate. However, as discussed throughout the task, rate or price of electricity may not be a suitable indication of value for several reasons. First, electricity is not valued in the market. The price is administered by a public utility commission. Secondly, the administered price is based on the embedded average cost of supplying power. The average cost pricing of electricity only includes the private market costs and not the externalities produced by electric generation. Finally, alternative pricing systems are likely to be implemented to some extent in the near future. The effects on the current rate structure will depend on the system selected. A multiattribute decision technique is, therefore, a useful tool in assessing the impact of changes in electrical rates attributable to plant construction and for comparing these effects to other decision criteria.

\section{ATTRIBUTES}

Customer classes were the selected attributes because of price differentiation, as illustrated in Table 2. Six attributes were selected:

residential customers of the local area, commercial customers of the local area, industrial customers of the local area, residential customers of the service area, commercial customers of the service area, and industrial customers of the service area. 
Customer classes were limited to residential, commercial and industrial because they are typically the largest customer classes and they are classified in most pricing schemes. In separating the customers between local and service area, we identify such differences as cost of supplying the power and external costs of electricity production. Local consumers are situated in communities or counties within close proximity to the site. Therefore, the cost (mills/kWh) of delivered power may be lower to local consumers because of little or no transmission costs, which may be reflected in lower rates. This has occurred where large industrial customers locate close to a plant to take advantage of busbar rates. Aiso, because local residents are impacted from the externalities of construction and operation of a power plant, any benefits of lower rates should be identified and considered.

The service area can cover a large geographic location; some larger utilities serve an entire state. The local customers may be part of the service area, aithough a utility is not restricted to site a power plant within its service area.

\section{ATTRIBUTE SIGNIFICANCE WEIGHTING}

The attributes (customer classes) will be weighted to distinguish their relative importance to the community (Figure 8 ). The attribute significance weighting will be determined by representatives from the community. The proposed plant would be sited near the community which implies local residents and normal business activity would be disrupted. We, therefore, believe that the local community representatives are better qualified to determine relative importance between the attributes. For example, the importance of an industry locating near the site is a community decision in which the residents would determine the advantages and disadvantages of industrial growth. The importance of the cost of electricity to the service area should also be determined at the local level where electricity is produced and most externalities occur.

There are various methods available for obtaining representative community samples. The best or preferred method will probably be unique for each community. Possibilities include a random community sample and 


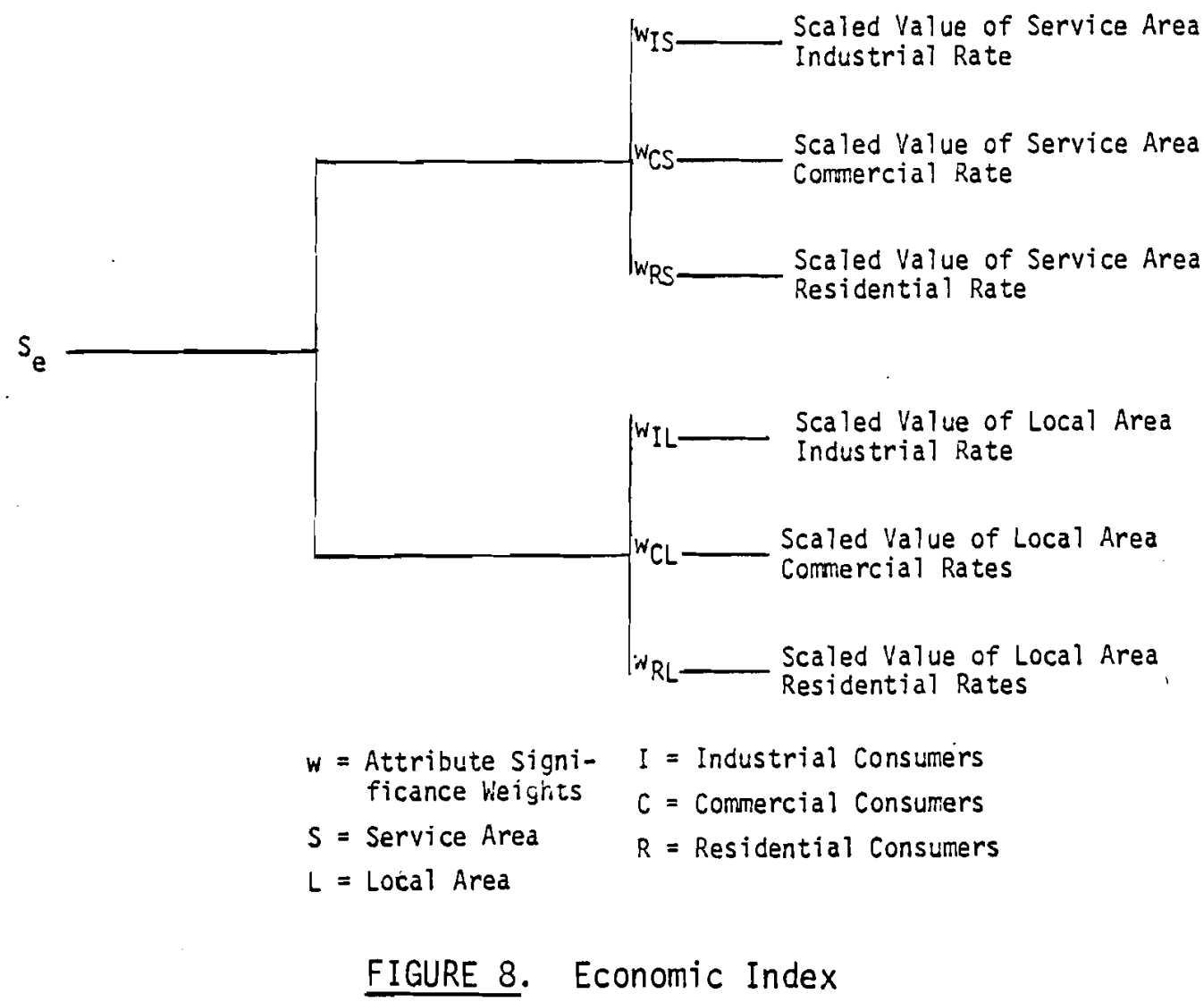

interviews with city council members. Several methods have been identified and tested in conjunction with assessment of the criteria weights for the overall site assessment methodology. (21) A recommended procedure for soliciting weights from the representative group is described in Appendix $A$.

\section{PARAMETER}

The basic parameter or measure of the economic index is electrical rates for each customer class. A scoring method for measuring the effects of a rate change from new plant construction has been developed from historical changes in the real price of electricity.

Nationally, electrical rates have decreased for the last 50 years with the exception of the last few years. The long-established trend of decreasing rates has been attributed to such factors as changes in technologies, low fuel costs and available hydro capacity. As shown in Figure 9, rates have 


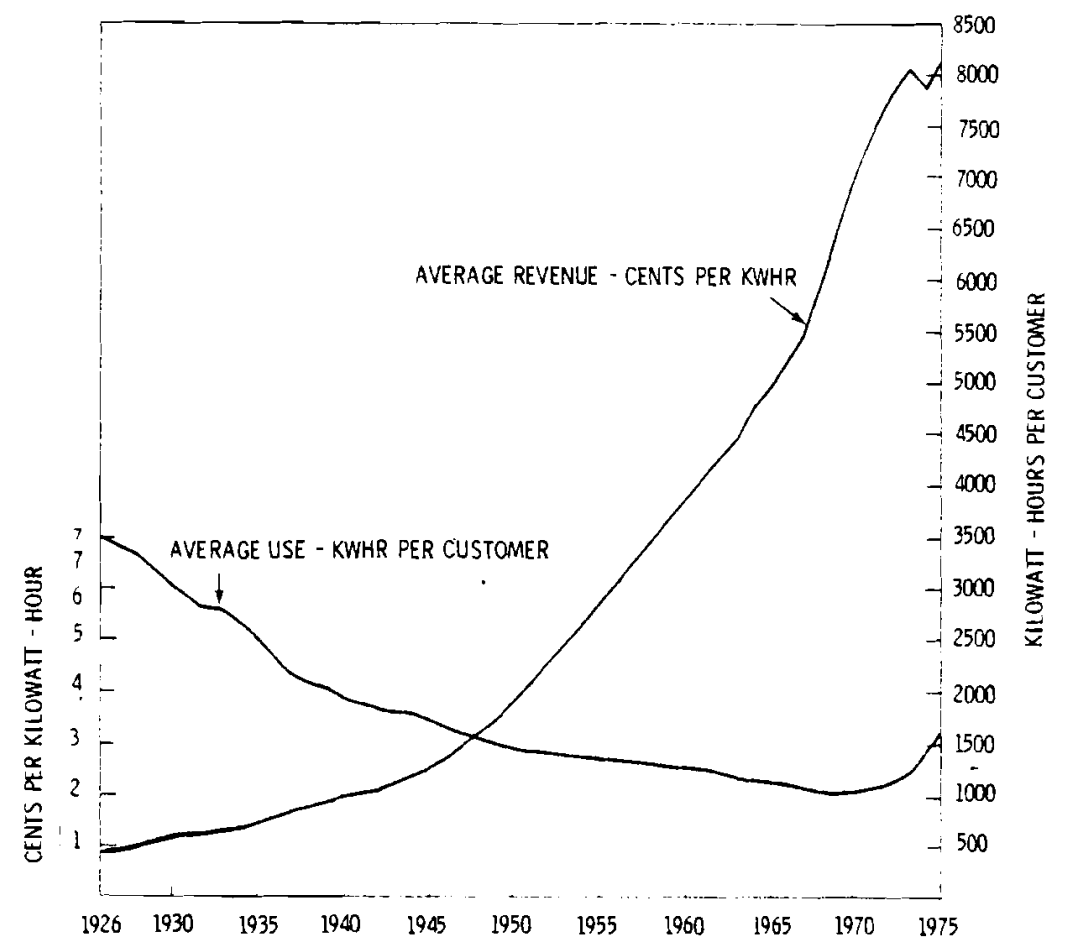

FIGURE 9. Residential Service for the Total Electric Utility Industry

increased nationally for the last five years even with a decrease in consumption in 1974. This recent trend in rising electricity rates have been received with much alarm by consumers and the commissions. Since rates are valued in current dollars, the increase in real dollars is not as signifirant al though any increase after a long-established trend is significant.

Many factors are attributed to rising cost in electrical power prices as previously discussed. Major. factors in rate increases are rising fuel costs, environmental regulations, siting delays, and general level of inflation. The capital cost of new capacity has gone up 104\% between 1969 and 1975 (14) $^{(14)}$

For purposes of assessment, we are assuming a rate increase to be a negative or adverse effect for the community. This is probably a reasonable assumption from the community's perspective. It is at least in accordance with the attitude of public utility commissions who are well known for their reluctance to approve rate increases. It can be argued, however, that rate 
increases may not be good for all individuals or society as a whole, for eventually, rate increases result in decreases in consumption because the quantity of electricity demanded is inversely related to price. A decrease in consumption of electricity has certain benefits; such as reduced pollution. However, it is not possible within the limits of this study to fully consider and weigh negative and positive effects of increasing electrical prices.

Estimating the rate change from new capacity with various design alternatives would involve several factors. A new plant entering a utility system would be embedded into a system of existing plants with escalating variable costs. This plant would be included in the rate base after construction which would be in the mid to late 1980's.

Assuming average cost pricing with price differentiation, the effects of new capacity on the rate structure would vary for each attribute (customer class). The average cost of new capacity would include the cost of distribution and transmission along with onsite generation. Therefore, for each attribute, the new rate resulting from plant construction would be estimated. Not only will alternative fuels, design and siting options effect the new electrical rates, but also the existing average cost and capacity of the system.

\section{$\underline{\text { SCALING }}$}

Once the parameter has been established, the next step is to score the parameter on a linear scale of importance, or value, ranging from 0 to 100 , where 0 reflects the best possible value and 100 the most severe value. When establishing a scaling function, it is important to consider all possible values of the parameter. Many times the parameter range will encompass values from 0 to infinity. (22) In those instances, the parameter range is estimated. When scoring the price of electricity, it is difficult to estimate the upper and lower range of parameter that would receive scores of 0 to 100.

The price of electricity would never command an infinite value because no one could buy it at that price. Likewise, electricity is a scarce good 
that has a price that reflects worth. Therefore, it is unlikely that the minimum range of an electrical rate parameter should be zero. We can, therefore, conclude that bounds of the range should be greater than zero and less than infinity. Using elasticity estimates, one might be able to estimate the price of electricity when no one could consume and assume at that price, the most severe impact occurs. However, the various estimates of elasticity available from literature are not always consistent with each other and probably not refined for service area assessment, let alone local areas.

We, therefore, propose an approach based on local historical electrical rates for each attribute. For each attribute, the minimum rate for the years between 1965 through 1970 will represent the "best possible" rate. On the scale of 0 to 100 , this would be 0 . During mid to late $1960^{\prime} \mathrm{s}$, the rates were declining in many regions and for the nation. The average rates during that interval we believe represent the minimal rates obtainable within today's utilities' planning horizon. Intermediate impact is defined based on the maximum real rate between 1971 and 1976. This rate will be assigned a value of 40 for most regions. However, in areas of rejatively low electrical rates, new base load capacity in the future will result in extreme rate increases. In those regions (generally, the Northwest and TVA service areas), the intermediate factor will be 10 based on the maximum rate from 1971 to 1976 levels. We will assume a linear relationship based on the two average points $(0,40)$ defined above and assume a linear scoring function or scale. Figure 10 illustrates the scaling function for the Northwest. The historical average rates are in 1975 dollars, where the minimum rate between 1965 and 1970 was about 9 mi $11 \mathrm{~s} / \mathrm{kWh}$ and the maximum average rate was about $12 \mathrm{mills} / \mathrm{kWh}$ between 1971 and 1975 .

\section{SUMMARY}

Figure 8 illustrates the economic index which incorporates the scaled parameter and weighted attributes. The formula below further illustrates the economic index.

$$
S_{e}=w_{I S}+w_{C S}+w_{R S}+w_{P L}+w_{C L}+w_{I L}
$$




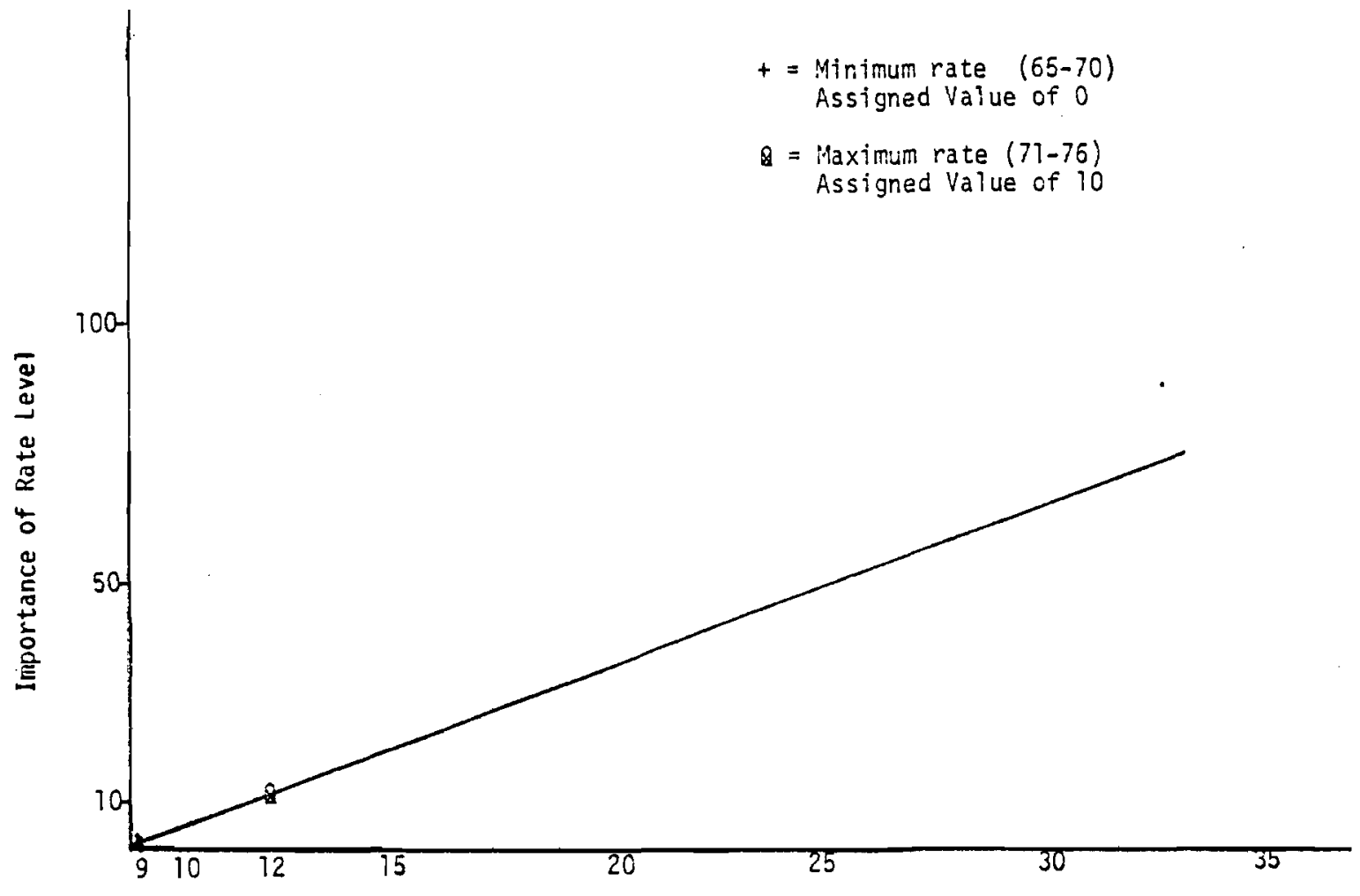

FIGURE 10. Price of Electricity in the Northwest (Mills/kWh) (\$ 1975)

(23)

where

$S_{e}=$ index of economic impact

$J=$ fuel, site, or design option

$w=$ weighting

$S=$ service area

$L=1$ local area

$I=$ industrial customers

$\mathrm{C}=$ commercial customers

$R=$ residential customers

$V=$ scaled value of the rates for each attribute.

This index will provide a method for measuring the effects of alternative site, design and fuel options on the price of electricity. The price of electricity under average cost pricing will vary depending on the design, fuel source and site alternatives. The electricity rate will 
also vary by customer class and rocation. The magnitude of the alternative will depend on the option and the utility system. For exampie, the selected cooling system will have only minimal effects on rate of electricity. In contrast, alternative site options could have significant effects on the price electricity for the local industrial customers. 


\section{REFERENCES}

1. J.C. Bonbright, Principles of Public Utility Rates, Columbia University Press, NY, 1961.

2. C.E. Ferguson and S.C. Maurice, Economic Analysis, Richard D. Irwin, Inc., Homewood, IL, 1970.

3. R.H. Sarikas and H. Herz, Electric Rate Concepts and Structures, Prepared for Bonneville Power Admin., U.S. Dept. of Commerce NTIS PB-252-905, Springfield, VA, 1976.

4. R.H. Leftwich, The Price System and Resource Allocation, The Dryden Press, Inc., Hinsdale, IL, 1970.

5. Nuclear and Coal-Fired Energy Cost for New York State - 1985, Battelle, Pacific Northwest Laboratories, prepared for Federal Energy Administration, Washington, D.C., December 1976.

6. U.S. Nuclear Regulatory Commission, Final Environmental Statement, NUREG-0176, Prepared for Black Fox Station Units 1 and 2, proposed by Public Service Company of Oklahoma, Docket Nos. STN 50-556; STN 50-557, NTIS, Springfield, VA, February 1977.

7. Federal Energy Administration,, Project Independence Blueprint Final Task Force Report - Coal, U.S. Department of the Interior, November 1974.

8. K.E. Nol1, W.T. Davis, Power Generation: Air Pollution Monitoring and Control, Ann Arbor Science Publishers Inc., 1976.

9. "EPRI Funds Dry Cooling Concept," Energy Research Digest, 3(16):10, 1977.

10. P.L. Hendrickson, An Overview of Economic, Legal, and Water Availability Factors Affecting the Demand for Dry and Wet/Dry Cooling for Thermal Power Plants, BNWL-2268, Prepared for the Energy Research and Development Administration under Contract EY-76-C-06-1830, Battelle, Pacific Northwest Laboratories, Richland, WA, June 1977.

11. Power Plant Capital Costs Current Trends and Sensitivity to Economic Parameters: U.S. Atomic Energy Commission, October 1974.

12. Final Environmental Statement Related to Construction of Washington Public Power Supply System Nuclear Projects 3 and 5 Washington Public Power Supply System, NUREG-75/053, June 1975, U.S. Nuclear Regulatory Commission, Office of Nuclear Reactor Regulation.

13. 0. Mende 1, "How Location Affects U.S. Plant-Construction Costs," Chemical Engineering, pp. 120-124, December 11, 1972. 
14. C.F. Phillips, Jr., The Economics of Regulation, Richard D. Irwin, Inc., Homewood, IL, 1969.

15. C.J. Cicchetti and J.L. Jurewitz, eds., Studies in Electric Utility Regulation, Ballinger Publishing Company, Cambridge MA, 1975.

16. The Challenge of Load Management - A Convergence of Diverse Interests, Proceedings of the Conference Held June 11-12, 1975, PB-244-576, FEA, U.S. Dept. of Commerce, NTIS, August 1975.

17. The 1970 National Power Survey. Federal Power Commission, Part I. A report by The Federal Power Commission, U.S. Government Printing Office, Washington, D.C., December 1971.

18. Statistics of Privately Owned Electric Utilities in the United States, 1975. Federa1 Power Commission, S-260, Washington, D.C.

19. Statistical Yearbook of the Electric Utility Industry for 1975. Edison Electric Institute, Pub. No. 76-51, October 1976.

20. Statistics of Publicly Owned Electric Utilities in the United States. Federal Power Comission, 19-4, Washington, D.C.

21. J. B. Burnham, et al., A Technique for Environmental Decision Making Using Quantified Social and Aesthetic Values. BNWL-1787, Battelle, Pacific Nortinest Laboratories, Richland, WA, February 1974.

22. J. R. Miller, III, A Systematic Procedure for Assessing the Worth of Complex Al ternatives. MTR-260, ESD-TR-67-90, Project 8510, The Mitre Corporation, Bedford, MA, November 1967.

23. T. P. Harrington and J. J. Jacobsen, ELSA An Electric Power Supply Analysis Model for Pacific Northwest. BNWL-2084. Battelle, Pacific Northwest Laboratories, Richland, WA, November 1976. 
APPENDIX A

DERIVING WEIGHTS FOR THE ATTRIBUTES 


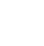

. 


\section{APPENDIX A: DERIVING WEIGHTS FOR THE ATTRIBUTES}

The procedure described in this appendix may be used to facilitate assessment of the relative weights of the attributes. First, a group of representatives from the affected community or locale is selected. This might be the same group assembled to establish the relative criteria weighting for the overall site/design assessment process. (a) Next, comprehensive background information is supplied to the participants, including discussion of the site/design proposals, potential rate effects, the site selection process and the meaning of the attributes. It should be emphasized that they are not being requested to assess the acceptability of rate levels as they presently exist in the community, but instead are to assess the importance, or significance of low rates with respect to each of the six attributes.

The panel is now requested to establish a rank ordering of significance among the six attributes. Column 1 of Table A-1 shows a possible ranking (a recommended ranking is not to be implied by this example).

Each attribute is now weighted relative to the other attributes. One method of accomplishing this is illustrated in Table A-1. Weights are first assigned by pair-wise comparison (Column 2) with the highest ranking member of each pair assumed to be weighted at 100 . Following assignment of pair-wise weights, all attributes are scaled relative to the 100 of the highest ranked attribute (Column 3, Table A-1).

Finally, the attribute weights are normalized to total to 1 (Column 4, Table A-1).

(a)J. B. Burnham, et al., A Technique for Environmental Decision Making Using Quantified Social and Aesthetic Values. BNWL-1787, Battelle, Pacific Northwest Laboratories, Richland, WA, February 1974. 
TABLE A-1. Suggested Method for Rank Ordering and Weighting Attributes

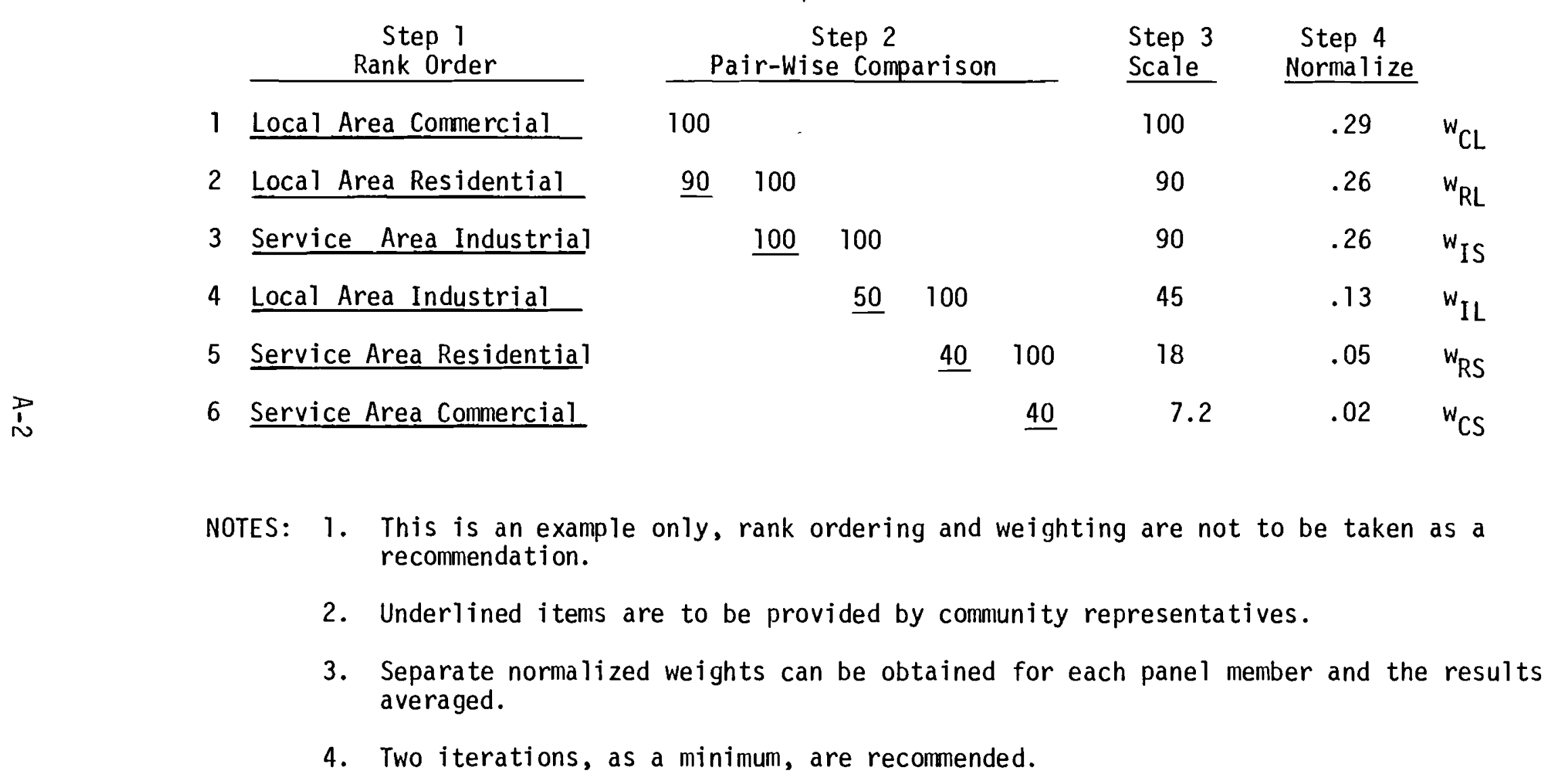




\section{DISTRIBUTION}

No. of

Copies

OFFSITE

A. A. Churm

ERDA Chicago Patent Group

9800 South Cass Avenue

Argonne, IL 60349

27 ERDA Technical Information Center

4 ERDA Division of Biomedical and Environmental Research Washington, D.C. 20545

D. S. Ballantine

R. P. Blaunstein

W. W. Burr

J. Swinebroad

W. E. Mott

ERDA Division of Environmenta] Control Technology

Washington, D.C. 20545

M. Reilly

ERDA Division of Fossil Energy

Washington, D.C. 20545.

H. L. Hollister

Deputy Assistant Administrator for Environment and Safety

Washington, D.C. 20545

J. L. Liverman

ERDA Assistant Administrator for Environment and Safety

Washington, D.C. 20545

J. Coleman

ERDA Office of Environmental

Policy Analysis

Washington, D.C. 20545
No. of

Copies

2 ERDA Division of Technology Overview

Washington, D.C. 20545

N. F. Barr

R. D. Cooper

A. B. Joseph

Office of Nuclear Regulatory

Research

U.S. NucTear Regulatory Commission Washington, D.C. 20555

E. Croke

Argonne National Laboratory

9700 South Cass Avenue

Argonne, IL 60439

P. M. Meier

Bidg. 475

Brookhaven Mational Laboratory

Upton, NY 11973

W. Siri

University of California - LBL

Lawrence Berkeley Laboratory

Berkeley, CA 94720

D. Layton

University of California - LLL

Lawrence Livermore Laboratory

P.0. Box 808

Livermore, CA 94550

E. Hammi 1

Los Alamos Scientific Laboratory

P.0. Box 1663

Los Alamos, NHI 87545

R. M. Davis

Oak Ridge National Laboratory

P.0. Box X

Oak Ridge, TN 37830 
DISTRIBUTION (Continued)

No. of

Copies

W. C. McConkey, Director

Division of Energy and Power

Development

Department of Commerce and

Economic Development

Mackay Building

338 Denali Street

Anchorage, AK 99501

D. Guss

Bureau of State Planning and Community Affairs

State House

Boise, ID 83720

M. O. Mortensen

Energy Advisory Council

c/o Lt. Governor's Office

Capitol Building

Helena, MT 59601

B. Foberts

State Land Use Planning Bureau

Department of Community Affairs

Capitol Post Office

Helena, MT 59601

A. C. Tsao

Energy Planning Division

Department of Natural Resources and Conservation

32 South Ewing

Helena, MT 59601

Maj. Gen. W. E. Peel

Division Engineer

North Pacific Division

Corps of Engineers

210 Custom House

Portland, OR 97209

Dr. K. Woods

Energy Facility Siting Division

Department of Energy

528 Cottage, N.E.

Salem, OR 97310
No. of

Copies

2 Jones and Jones

$105 \mathrm{~S}$. Main St.

Seattle, WA 98104

Grant R. Jones

Kenneth Caldwell

R. Polzin

Energy Facilities Site

Evaluation Council

820 East Fifth Avenue

Olympia, WA 98504

L, K. Hal1, Director

Idaho Energy Office

State House

Boise, ID 83720

L. Bradley

Washington State Energy Office

1000 Cherry

Olympia, WA 98504

D. B. Freudenthal

State Planning Coordinator's

Office

Office of the Governor

State Capitol

Cheyenne, WY 82002

F. C. Blood

Bonneville Power Administration

P.0. Box 362T

Portland, OR 97208

M. Katz

Northwest Energy Policy Project

1096 Lloyd Building

700 N.E. Multnomah Street

Portland, OR 97232

W. E. Bruner

Pacific Northwest Regional Commission 205 Washington

Vancouver, WA 98660 
No. of

Copies

2 Portland General Electric Co.

621 S.W. Alder Street

Portland, OR 97205

$$
\begin{aligned}
& \text { H. S. Johnson } \\
& \text { J. L. Williams }
\end{aligned}
$$

H. Kosmata

Washington Public Power Supply

System

3000 George Washington Way

Richland, WA 99352

J. W. Ellis

Puget Sound Power and Light Co.

Puget Power Building

Bellevue, INA 98009

Rene Males

Electric Power Research Institute

3412 Hillview Avenue

P.0. Box 10412

Palo Alto, CA 94304

R. Sheehan

City of Seattle

Department of Lighting

1015 Third Avenue

Seattle, WA 98104

H. C. ETmore

Pacific Northwest Utilities

Conference Committee

P.0. Box 1231

Wenatchee, WA 98801

R. A. Hofacker

Montana Power Company

40 East Broadway

Butte, MT 59701

R. H. Bendio

Idaho Power Company

P.0. Box 70

Boise, ID 83721
No. of

Copies

H. W. Harding

Washington Water Power Company

P.0. Box 3727

Spokane, WA 99220

H. G. Curtis

Public Power Council

P.0. Box 1307

Vancouver, WA 98660

J. T. Stiles

Pacific Power and Light

Portland, OR 97204

7 Battelle-Northwest

Human Affairs Research Center (HARC)

J. A. Hebert

M. R. Greene

D. J. Merwin

ONSITE

4 ERDA Richland Operations Office

P. W. Gottschalk

G. L. Liffick

R. H. Lindsey

B. J. Melton

42 Battelle-Northwest 
